\title{
Dual Effects of Theophylline on Spontaneous Transmitter Release from Frog Motor Nerve Terminals
}

\author{
Susan R. Barry \\ Department of Physical Medicine and Rehabilitation, University Hospital, University of Michigan, Ann Arbor, Michigan \\ 48109-0042
}

\begin{abstract}
Alkylxanthine drugs, such as theophylline, block adenosine receptors, inhibit phosphodiesterases and other enzymes, and cause the release of calcium from intracellular stores. Adenosine receptor blockade occurs at low micromolar concentrations of the drugs, while other effects occur in the millimolar concentration range.
\end{abstract}

The effects of theophylline were tested on spontaneous transmitter release at the frog cutaneous-pectoris neuromuscular junction (NMJ). A change in the frequency, but not the amplitude, of miniature endplate potentials (mepps) was interpreted as a change in spontaneous transmitter release. In normal Ringer's, theophylline, at concentrations of $100 \mu \mathrm{M}$ and $1 \mathrm{~mm}$, enhanced spontaneous transmitter output, while at $10 \mu \mathrm{M}$, theophylline had no consistent effect on spontaneous release. In contrast, theophylline produced dual effects on mepp frequency in hyperosmotic Ringer's. At 10 $\mu \mathrm{M}$, theophylline depressed mepp frequency, while, at 100 $\mu \mathrm{M}$ and $1 \mathrm{mM}$, theophylline increased mepp rate.

Since low micromolar concentrations of theophylline depressed spontaneous transmitter release, this action may result from adenosine receptor blockade and inhibition of a tonic, stimulatory effect of adenosine. This hypothesis was supported by the following experimental results: (1) Micromolar concentrations of theophylline reversed the effects of applied adenosine on neuromuscular transmission. (2) The inhibitory effect of theophylline was mimicked by 2 other alkylxanthines, 8-phenyltheophylline and 8-p-sulfophenyltheophylline. These drugs may be more specific adenosine receptor antagonists than theophylline. (3) The inhibitory effect of theophylline was mimicked by adenosine deaminase, an enzyme that breaks down and inactivates adenosine. (4) The depressant action of theophylline was masked by the addition of adenosine deaminase to the hyperosmotic Ringer's.

Application of adenosine to the frog NMJ reduces spontaneous transmitter output. Yet, theophylline, in hyperosmotic Ringer's, depressed mepp frequency probably by

\footnotetext{
Received Nov, 19, 1987; revised Apr. 5, 1988; accepted May 6, 1988

This research was supported by NSF Grant BNS 8506778 and a Kuffler fellowship from the Marine Biological Laboratory. I thank Dr. George J. Augustine for teaching me the cutaneous-pectoris nerve-muscle preparation, Dr. John $\Lambda$. Faulk ner for his support and encouragement, Dr. William Ericson for help with statistics and Denise D. Dyson for secretarial assistance. Ro20-1724 was graciously provided by Hoffmann-La Roche Inc. This research was done, in part, at the Marine Biological Laboratory in Woods Hole, MA.

Correspondence should be addressed to Susan R. Barry, Department of Physical Medicine and Rehabilitation, University Hospital, Room 1D204, 1500 East Medical Center Drive, Ann Arbor, MI 48109-0042.

Copyright $(C) 1988$ Society for Neuroscience $0270-6474 / 88 / 124427-07 \$ 02.00 / 0$
}

adenosine receptor blockade and inhibition of the effects of endogenous adenosine. This paradox may be explained if adenosine has more than one action on spontaneous transmitter release from frog motoneurons.

The alkylxanthine, theophylline, affects the activity of excitable cells by several different mechanisms. At micromolar concentrations, theophylline blocks adenosine receptors (Sattin and Rall, 1970; Smellie et al., 1979; Daly et al., 1981), while, at millimolar concentrations, theophylline may deprcss the activity of several enzymes, including phosphodiesterases (Butcher and Sutherland, 1962; Fain et al., 1972; Fredholm et al., 1978; Smellie et al., 1979), 5'-nucleotidase (Tsuzuki and Newburgh, 1975; Fredholm et al., 1978), and alkaline phosphatase (Fredholm et al., 1978; Croce et al., 1979). In addition, millimolar concentrations of methylxanthines may cause the release of calcium from intracellular stores (Bianchi, 1968).

Theophylline enhances acetylcholine (ACh) release from vertebrate motoneurons (Goldberg and Singer, 1969; Ginsborg and Hirst, 1972; Wilson, 1974; Ribeiro and Sebastião, 1987). This effect has been attributed both to phosphodiesterase inhibition (Goldberg and Singer, 1969; Wilson, 1974) and adenosine receptor blockade (Ginsborg and Hirst, 1972; Ribeiro and Sebastião, 1987). Since application of adenosine usually depresses transmitter release from motor nerve terminals (Ginsborg and Hirst, 1972; Ribeiro and Walker, 1975; Brãnisteanu et al., 1979; Silinsky, 1984), theophylline may enhance ACh output by blocking a tonic, depressant effect of endogenous adenosine.

The concentrations of theophylline that have been studied at the vertebrate neuromuscular junction (NMJ) have been in the millimolar or high micromolar concentration range (Goldberg and Singer, 1969; Ginsborg and Hirst, 1972; Wilson, 1974; Ribeiro and Sebastião, 1987). At such high concentrations, the drug may affect neuromuscular transmission by more than one mechanism. If theophylline enhances transmitter release by adenosine receptor blockade, its effects may be seen at micromolar concentrations (Smellie et al., 1979; Daly et al., 1981). If, however, the drug increases $\mathrm{ACh}$ output by inhibition of phosphodiesterase or other enzymes or by causing the release of intracellular calcium, its effects may be observed only at millimolar concentrations (Bianchi, 1968; Tsuzuki and Newburgh, 1975; Fredholm et al., 1978; Smellie et al., 1979).

I have studied the effects of theophylline on spontaneous transmitter release from frog motoneurons. In normal Ringer's, theophylline, at 10 and $20 \mu \mathrm{M}$, produced no consistent effect on spontaneous transmitter output, while, at concentrations equal to or greater than $100 \mu \mathrm{M}$, theophylline enhanced spontaneous $\mathrm{ACh}$ release. In contrast, in hyperosmotic Ringer's solution, 


\begin{tabular}{|c|c|c|c|c|}
\hline \multirow{2}{*}{$\begin{array}{l}\text { Theo- } \\
\text { phylline } \\
\text { dose }\end{array}$} & \multicolumn{4}{|c|}{ Percentage change in mepp frequency } \\
\hline & Normal Ringer's & Mean \pm SEIM & $\begin{array}{l}\text { Hyperosmotic } \\
\text { Ringer's }\end{array}$ & Mean $\pm \mathrm{SEM}$ \\
\hline \multirow[t]{4}{*}{$10 \mu \mathrm{M}$} & -22 & & $-44^{a}$ & \\
\hline & +0.7 & & $-42^{a}$ & \\
\hline & +7 & & $-29 a$ & \\
\hline & $+42^{a}$ & $+6.9 \pm 13.2$ & -19 & $-33.5 \pm 5.9$ \\
\hline \multirow[t]{4}{*}{$20 \mu \mathrm{M}$} & -17 & & -21 & \\
\hline & -11 & & -12 & \\
\hline & +25 & $-1.0 \pm 13.1$ & $+30^{a}$ & \\
\hline & & & $+53^{a}$ & $+12.5 \pm 17.4$ \\
\hline \multirow[t]{4}{*}{$100 \mu \mathrm{M}$} & +45 & & $+26^{a}$ & \\
\hline & $+53^{a}$ & & $+68^{a}$ & \\
\hline & $+55^{a}$ & & $+77^{a}$ & $+57.0 \pm 15.7$ \\
\hline & $+62^{a}$ & $+53.8 \pm 3.5$ & & \\
\hline \multirow[t]{3}{*}{$1 \mathrm{~mm}$} & $+59^{a}$ & & $+80^{a}$ & \\
\hline & $+71^{\circ}$ & & $+102^{a}$ & \\
\hline & $+73^{a}$ & $+67.7 \pm 4.4$ & $+128^{a}$ & $+103.3 \pm 13.9$ \\
\hline
\end{tabular}

\footnotetext{
At concentrations of 10 and $20 \mu \mathrm{M}$, theophylline did not produce a consistent effect on mepp frequency in normal Ringer's, but, at $10 \mu \mathrm{M}$, theophylline consistently depressed mepp frequency in hyperosmotic Ringer's. At $100 \mu \mathrm{M}$ and $1 \mathrm{~mm}$, theophylline enhanced mepp frequency both in normal and hyperosmotic Ringer's. A 2-sample Student's $t$ test was used to compare in each preparation mean mepp frequencies in the presence and absence of theophylline.

${ }^{a} p \leq 0.05$.
}

theophylline produced dual effects on spontaneous transmitter release. At millimolar concentrations $(0.1$ and $1.0 \mathrm{~mm})$, theophylline enhanced spontaneous transmitter release from frog motoneurons, while, at low micromolar concentrations $(10 \mu \mathrm{M})$, theophylline depressed spontaneous transmitter output. This depressant effect of theophylline was mimicked by the enzyme adenosine deaminase and may therefore result from blockade of adenosine receptors and inhibition of the effects of endogenous adenosine (Daly, 1982). However, application of adenosine to the frog NMJ also reduces spontaneous transmitter output (Ribeiro and Walker, 1975; Brãnisteanu et al., 1979; Silinsky, 1984). These results suggest that adenosine both stimulates and inhibits spontaneous transmitter release from frog motoneurons. A preliminary report of this research has appeared (Barry, 1986a).

\section{Materials and Methods}

The cutaneous-pectoris nerve-muscle preparation was isolated from small frogs (Rana pipens, $1 \frac{11}{2}$ to $2 \frac{1}{2}$ inches, Kons Scientific, Germantown, WI). The nerve-muscle preparation was placed in a recording dish and continually perfused with frog Ringer's (115 mM NaCl, $1.8 \mathrm{mM} \mathrm{CaCl}_{2}$, $2 \mathrm{~mm} \mathrm{KCl}, 5 \mathrm{~mm}$ glucose, $5 \mathrm{~mm}$ Tris $\mathrm{HCl}$, pH 7.2). Hyperosmotic Ringer's solution was made by adding $24 \mathrm{~mm}$ sucrose to the Ringer's. Intracellular recordings of miniature endplate potentials (mepps) were made with $20-40 \mathrm{~m} \Omega$ glass electrodes placed in the endplate region of the muscle fiber. Recordings were amplified on a Biodyne AM-4 amplifier, displayed on a Tektronix 5113 oscilloscope, and stored on an Indec IR-2 data recorder or photographed on a Grass Kymograph camera. Microelectrodes were usually filled with $3 \mathrm{M} \mathrm{KCl}$. In most cases, muscle resting potentials of about $-95 \mathrm{mV}$ could be obtained for several hours. During the winter, however, the resting potential of the muscle fibers tended to depolarize over time. The problem was corrected by filling the microelectrodes with a $250 \mathrm{~mm} \mathrm{KCl}$ solution as opposed to a $3 \mathrm{M} \mathrm{KCl}$ solution. This change in the filling solution reduced the muscle resting potential by about $10 \mathrm{mV}$ but had no other effects on the experimental results. Recordings were made at $18-21^{\circ} \mathrm{C}$. Bath temperature was controlled by a peltier device. In any one experiment, the temperature did not vary by more than $1^{\circ} \mathrm{C}$.

A change in mepp frequency that was not accompanied by a change in mepp size was interpreted as a change in spontaneous transmitter release (Katz, 1969). Mean mepp frequency was measured by counting the number of mepps occurring during $30-60$ consecutive $10 \mathrm{sec}$ recording periods in each solution and averaging these values. Mean mepp frequencies obtained from one preparation recorded in different solutions were compared using the 2 sample Student's $t$ test. Since the effects of all the drugs tested were reversible, mean mepp frequencies in the presence of the drugs were compared with the mean frequency recorded in Ringer's solution before and after exposure to the drug. The effects of all drugs tested developed within $10 \mathrm{~min}$ and reversed within $30 \mathrm{~min}$. Mepp frequencies were measured at least $10 \mathrm{~min}$ after addition of the drugs. Histograms of mepp size were obtained by plotting the mepp amplitude in $0.05-0.2 \mathrm{mV}$ bins and plotting these amplitude bins against the frequency of their occurrence. Mepp size histograms obtained from one endplate in different recording solutions were compared statistically using the Kolmogorov-Smirnov test.

Adenosinc, 8-p-sulfophenylthcophyllinc, the enzyme, adenosine deaminase, and Ro20-1724, were dissolved directly into frog Ringer's. Theophylline and 8-phenyltheophylline, at concentrations of $1-100 \mathrm{~mm}$, were dissolved in $0.1 \mathrm{~N} \mathrm{NaOH}$ and diluted with Ringer's to a final concentration of $1 \mu \mathrm{M}-1 \mathrm{~mm}$. Drugs were added by perfusion.

Adenosine, theophylline, 8-phenyltheophylline, and adenosine deaminase (type I and X) were obtained from Sigma Chemical Co. (St. Louis), while 8-p-sulfophenyltheophylline was purchased from Research Biochemicals, Inc. (Wayland, MA). Ro20-1724 was kindly provided by Hoffmann-La Roche Inc. (Nutley, NJ).

\section{Results}

\section{Effects of theophylline in normal Ringer's}

At concentrations of 0.1 and $1.0 \mathrm{~mm}$, theophylline reversibly enhanced mepp frequency in normal Ringer's solution by 45$73 \%$ (Table 1). This effect was not accompanied by a change in mepp amplitude. At concentrations of 10 and $20 \mu \mathrm{M}$, theophylline produced no consistent effect on mepp frequency (Table 1). At $10 \mu \mathrm{M}$, the drug did not alter the resting potential of the muscle or mepp size. 


\section{HYPEROSMOTIC RINGER}

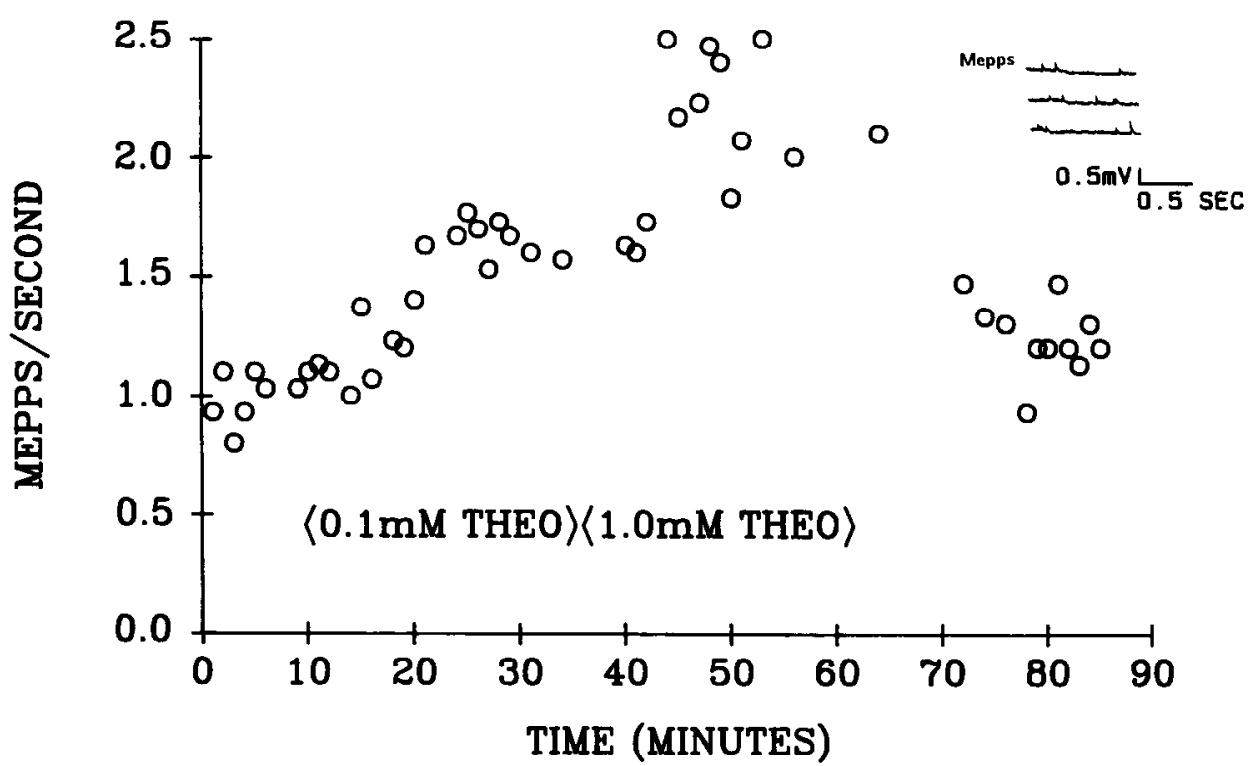

Figure 1. Stimulatory effects of 0.1 and $1.0 \mathrm{~mm}$ theophylline on mepp frequency in hyperosmotic Ringer's. Mepp frequencies for $30 \mathrm{sec}$ recording periods were plotted against time. Theophylline enhanced mepp rate by $77 \%(p<0.001)$ at $0.1 \mathrm{~mm}$ and by $102 \%(p<0.001)$ at $1.0 \mathrm{~mm}$. This effect was reversible. Inset, A recording of mepps. Theo, theophylline.

\section{Effects of theophylline in hyperosmotic Ringer's}

Since resting mepp frequency was often quite low (i.e., $<10$ $\mathrm{mepps} / \mathrm{min}$ ), mepp frequency was artificially elevated in many experiments by increasing the osmolarity of the Ringer's with the addition of $24 \mathrm{~mm}$ sucrose (Fatt and Katz, 1952; Furshpan, 1956; Shimoni et al., 1977). This increase in osmolarity enhanced mepp rate by $2-$ to 4 -fold. Under these conditions, theophylline, at concentrations of 0.1 and $1.0 \mathrm{~mm}$, elevated mepp frequency by $26-128 \%$, an effect similar to its action in normal Ringer's (Fig. 1, Table 1). However, application of $10 \mu \mathrm{M}$ theophylline produced a different effect on mepp frequency in hyperosmotic Ringer's than normal Ringer's. In hyperosmotic Ringer's, $10 \mu \mathrm{M}$ theophylline reversibly depressed mepp frequency by an average of $34 \%$ (Fig. 2, Table 1). This action was not accompanied by any observable postsynaptic effects.

At a concentration as low as $10 \mu \mathrm{M}$, theophylline may act as an adenosine receptor antagonist but may have little activity as an inhibitor of phosphodiesterase, $5^{\prime}$-nucleotidase, or alkaline phosphatase, or as a mobilizer of intracellular calcium stores. Therefore, the effect of theophylline on mepp frequency recorded in hyperosmotic Ringer's may result from adenosine receptor blockade.

\section{Antagonism by theophylline of the effects of adenosine}

Experiments were then designed to determine if micromolar concentrations of theophylline could block the effects of exogenous adenosine on neuromuscular transmission. In both normal and hyperosmotic Ringer's, addition of $10 \mu \mathrm{M}$ adenosine to the frog NMJ reduced mepp frequency by $40-50 \%$. A $40-$ $50 \%$ decrease in mepp frequency is the maximum effect of adenosine on spontaneous transmitter release (Ribeiro and Sebastião, 1986). This action was partially reversed by $10 \mu \mathrm{M}$ theophylline in 1 out of 3 experiments in which mepps were recorded in normal Ringer's and in 1 out of 2 experiments in which mepps were recorded in hyperosmotic Ringer's (Table 2). Theophylline, $10 \mu \mathrm{M}$, also partially reversed the effects of 2 $\mu \mathrm{M}$ adenosine in one experiment in hyperosmotic Ringer's. At
$20 \mu \mathrm{M}$, theophylline completely blocked the effects of $10 \mu \mathrm{M}$ adenosine in 3 out of 3 experiments in which mepps were recorded in normal Ringer's (Fig. 3, Table 2). Therefore, micromolar concentrations of theophylline are capable of inhibiting the effects of maximum doses of adenosine.

\section{Effects of other aklylxanthine drugs}

The effects of theophylline were mimicked by other alkylxanthine drugs. 8-Phenyltheophylline did not alter mepp frequency in normal Ringer's ( 2 experiments), but in 2 out of 3 preparations, $1 \mu \mathrm{M}$ 8-phenyltheophylline depressed mepp frequency in hyperosmotic Ringer's by $24 \%(p<0.02)$ and $30 \%(p<0.001)$

\begin{tabular}{|c|c|c|c|c|c|}
\hline \multirow[b]{2}{*}{$\begin{array}{l}\text { Experi- } \\
\text { ment }\end{array}$} & \multirow[b]{2}{*}{ Ringer's } & \multirow[b]{2}{*}{$\begin{array}{l}\text { Adeno- } \\
\text { sine } \\
(\mu \mathrm{M})\end{array}$} & \multirow[b]{2}{*}{$\begin{array}{l}\text { Theo- } \\
\text { phylline } \\
(\mu \mathrm{M})\end{array}$} & \multicolumn{2}{|c|}{$\begin{array}{l}\% \text { of control } \\
\text { mepp frequency }\end{array}$} \\
\hline & & & & $\begin{array}{l}\text { Adeno- } \\
\text { sine }\end{array}$ & $\begin{array}{l}\text { Adeno- } \\
\text { sine + } \\
\text { theo- } \\
\text { phylline }\end{array}$ \\
\hline 1 & HR & 2 & 10 & 51 & $66^{a}$ \\
\hline 2 & HR & 10 & 10 & 24 & $32^{a}$ \\
\hline 3 & HR & 10 & 10 & 53 & 53 \\
\hline 4 & NR & 10 & 10 & 35 & $59^{a}$ \\
\hline 5 & NR & 10 & 10 & 58 & 67 \\
\hline 6 & NR & 10 & 10 & 55 & 59 \\
\hline 7 & NR & 10 & 20 & 58 & $115^{a}$ \\
\hline 8 & NR & 10 & 20 & 56 & $117^{a}$ \\
\hline 9 & NR & 10 & 20 & 56 & $98^{a}$ \\
\hline
\end{tabular}

At a concentration of $10 \mu \mathrm{M}$, theophylline partially reversed the inhibitory effects of $10 \mu \mathrm{M}$ adenosine on mepp frequency, while, at $20 \mu \mathrm{M}$, theophylline completely blocked the actions of $10 \mu \mathrm{M}$ adenosine. A 2-sample Student's $t$ test was used to compare, in one preparation, mean mepp frequencies recorded in adenosine and frequencies recorded in adenosine with theophylline. NR, normal Ringer's; HR, hyperosmotic Ringer's.

${ }^{a} p \leq 0.05$. 
Figure 2. Inhibitory effect of $10 \mu \mathrm{M}$ theophylline on mepp frequency in hyperosmotic Ringer's. $A$, mepp frequencies for $6 \mathrm{sec}$ recording periods plotted against time. Theophylline reduced mepp frequency by $43 \%(p<0.01) . B$ Amplitudes of 100 mepps recorded in the absence and 100 mepps recorded in the presence of $10 \mu \mathrm{M}$ theophylline were grouped into $0.05 \mathrm{mV}$ size bins and plotted against the frequency of their occurrence. Theophylline did not affect the mepp amplitude distribution $(p>$ $0.10)$. Theo, theophylline.

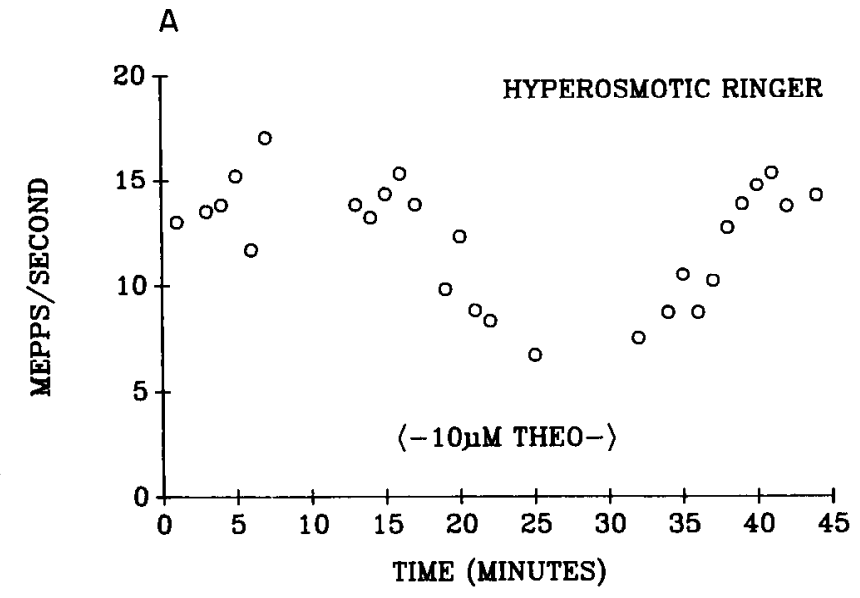

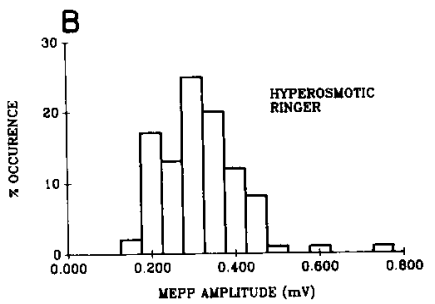

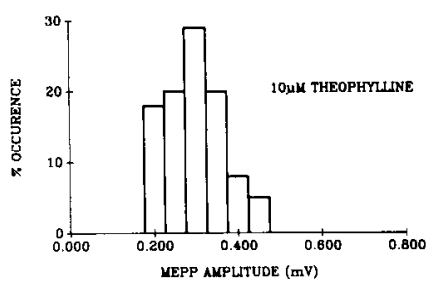

(Fig. 4). In a third experiment in hyperosmotic Ringer's, 8-phenyltheophylline did not alter mepp rate. The drug did not affect the resting potential of the muscle or mepp size. In 2 out of 2 experiments, $1 \mathrm{~mm} 8$-p-sulfophenyltheophylline depressed mepp frequency in hyperosmotic Ringer's by $34 \%(p<0.001$ for both preparations) but had no effect on the muscle resting potential or mepp size.

\section{Effects of adenosine deaminase}

If theophylline depresses mepp frequency by adenosine receptor blockade, then its effects should be mimicked by adenosine deaminase, an enzyme that inactivates adenosine (Daly, 1982). Application of adenosine deaminase, at doses of $2.5 \mathrm{units} / \mathrm{ml}$, reversed the depressant effect of $10 \mu \mathrm{M}$ adenosine on mepp frequency. At a concentration of $0.1 \mathrm{unit} / \mathrm{ml}$, adenosine deaminase reversibly reduced mepp frequency in hyperosmotic Ringer's by $30 \%(p<0.01), 32 \%(p<0.02)$, and $40 \%(p<$ 0.001 )(Fig. 5). Application of 0.5 units $/ \mathrm{ml}$ adenosine deaminase reversibly decreased spontaneous transmitter output by $20 \%(p$ $<0.01), 24 \%(p<0.001), 35 \%(p<0.01), 42 \%(p<0.001)$, $65 \%(p<0.001)$, and $73 \%(p<0.001)$. Adenosine deaminase at a concentration of $1.0 \mathrm{unit} / \mathrm{ml}$ reduced mepp frequency by $40 \%(p<0.001)$ in one preparation and enhanced mepp rate by $21 \%(p<0.05)$ in a second experiment. These actions were not accompanied by any observable postsynaptic effects, At these concentrations, adenosine deaminase did not alter mepp frequency in normal Ringer's ( 2 experiments, Fig. 5). Thus, the actions of adenosine deaminase paralleled the effects of theophylline on spontaneous transmitter output.

Application of adenosine deaminase to the frog NMJ masked the inhibitory effects of theophylline on mepp frequency (Fig. 6). A concentration of 0.5 units $/ \mathrm{ml}$ of adenosine deaminase was chosen since this concentration produced a maximal inhibitory effect on spontancous relcasc. In 3 out of 3 expcriments, mepp frequency was reduced in 0.5 units $/ \mathrm{ml}$ adenosine deaminase. No further decrease in mepp frequency was produced by the subsequent addition of $10 \mu \mathrm{M}$ theophylline to the Ringer's containing adenosine deaminase. In contrast, in the same preparations, application of $10 \mu \mathrm{M}$ theophylline, in the absence of adenosine deaminase, depressed spontaneous release.

\section{Effects of Ro20-1724, a phosphodiesterase inhibitor}

Since theophylline, at millimolar concentrations, may act as a phosphodiesterase inhibitor, the effects of the phosphodiesterase inhibitor, Ro20-1724, were also tested on spontaneous ACh release at the frog NMJ. In normal Ringer's, Ro20-1724 re-

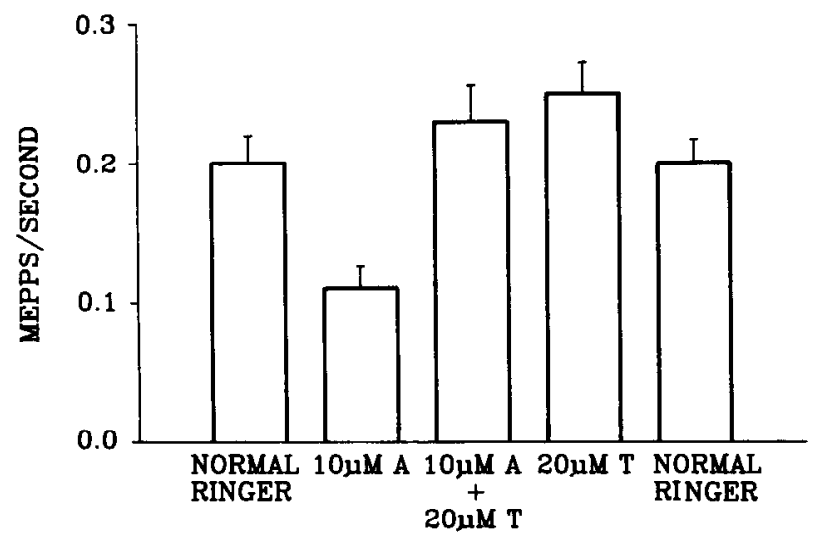

Figure 3. Antagonism of the inhibitory effect of adenosine on mepp frequency by theophylline. Data represent the mean \pm SEM of mepp frequencies recorded during one experiment. Adenosine, at $10 \mu \mathrm{M}$, reduced mepp frequency by $45 \%$, an effect completely reversed by $20 \mu \mathrm{M}$ theophylline. Theophylline enhanced basal mepp frequency by $25 \%$, but this effect was not statistically significant $(p<0.1)$. $A$, adenosine; $T$, theophylline.

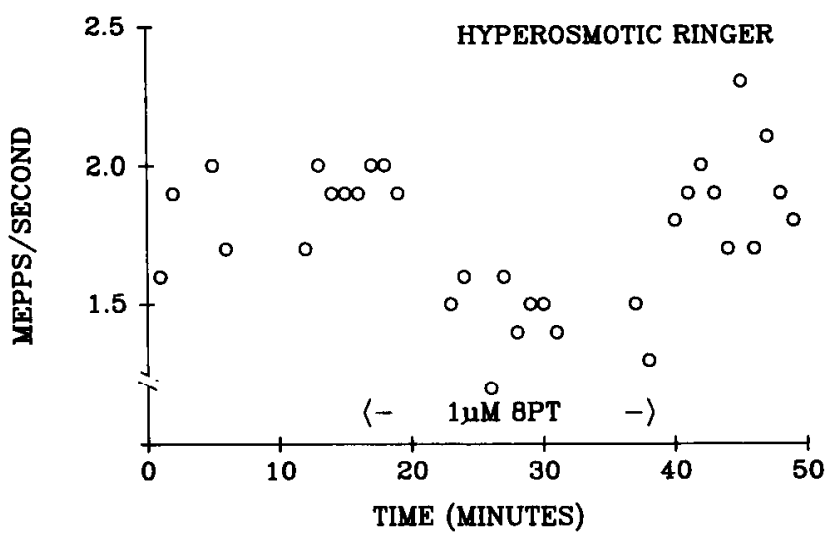

Figure 4. Inhibitory effect of $1 \mu \mathrm{M} 8$-phenyltheophylline on mepp frequency in hyperosmotic Ringer's. Mepp frequencies for $30 \mathrm{sec}$ recording periods were plotted against time. 8-Phenytheophylline reversibly depressed mepp frequency by $30 \%(p<0.001) .8 P T, 8$-phenyltheophylline. 


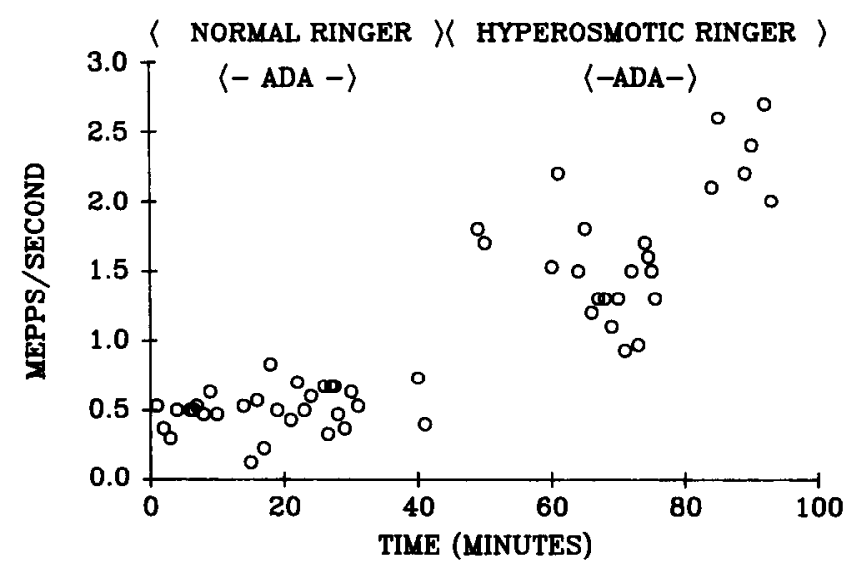

Figure 5. Inhibitory effect of adenosine deaminase on mepp frequency in hyperosmotic but not normal Ringer's. Mepp frequencies for $30 \mathrm{sec}$ recording periods were plotted against time. Adenosine deaminase $(0.1$ units $/ \mathrm{ml})$ did not significantly affect mepp rate in normal Ringer's $(13 \%$ increase, $p<0.2$ ) but significantly reduced mepp frequency by $40 \%(p$ $<0.001$ ) in hyperosmotic Ringer's. Data represent a continuous recording from one endplate. $A D A$, adenosine deaminase.

versibly elevated mepp frequency by $49 \%$ at $60 \mu \mathrm{M}(p<0.05)$, by $104 \%(p<0.001)$ at $100 \mu \mathrm{M}$, and by $465 \%(p<0.001)$ at $300 \mu \mathrm{M}$. This action was accompanied by a decrease in mepp size (Fig. 7). Silinsky (1984) and Silinsky and Vogel (1987) have also reported that Ro20-1724 increases mepp frequency and reduces the size of the endplate current.

\section{Discussion}

\section{Stimulatory effects of theophylline}

In normal and hyperosmotic Ringer's solution, theophylline, at concentrations at or above $100 \mu \mathrm{M}$, enhanced spontaneous transmitter release from frog motoneurons. Theophylline is an adenosine receptor antagonist (Sattin and Rall, 1970; Smellie et al., 1979; Daly et al., 1981). Application of $10 \mu \mathrm{M}$ adenosine to the frog NMJ depressed spontaneous ACh output, an effect that was reversed by $20 \mu \mathrm{M}$ theophylline. Thus, theophylline may potentiatc spontancous transmitter release by blockade of adenosine receptors and inhibition of a tonic depressant effect of endogenous adenosine. Similarly, Ribeiro and Sebastião (1987) have reported that theophylline, at concentrations of 100 and 200 $\mu \mathrm{M}$, enhances evoked transmitter release at the frog $\mathrm{NMJ}$, an effect that may result from reduction of a tonic, inhibitory action of endogenous adenosine.

At concentrations greater than or equal to $100 \mu \mathrm{M}$, theophylline may also affect neuromuscular transmission by mechanisms other than adenosine receptor blockade. For example, theophylline inhibits phosphodiesterases in the rat brain with an $\mathrm{IC}_{50}$ of $500 \mu \mathrm{M}-1 \mathrm{~mm}$ (Smellie et al., 1979). The effect on transmitter release of increases in cyclic AMP levels in motor nerve terminals has not been resolved (Miyamoto and Breckenridge, 1974; Wilson, 1974; Dretchen et al., 1976; Silinsky, 1984). However, application of the phosphodiesterase inhibitor Ro20-1724 to the frog NMJ enhanced mepp frequency, an action similar to that of theophylline. Silinsky (1984) and Silinsky and Vogel (1987) have also reported that Ro20-1724 and other phosphodiesterase inhibitors increase mepp frequency. Thus, theophylline, at $100 \mu \mathrm{M}$ and $1 \mathrm{mM}$, may increase spontaneous transmitter release in part by phosphodiesterase inhibition and enhancement of intraterminal cyclic AMP levels.

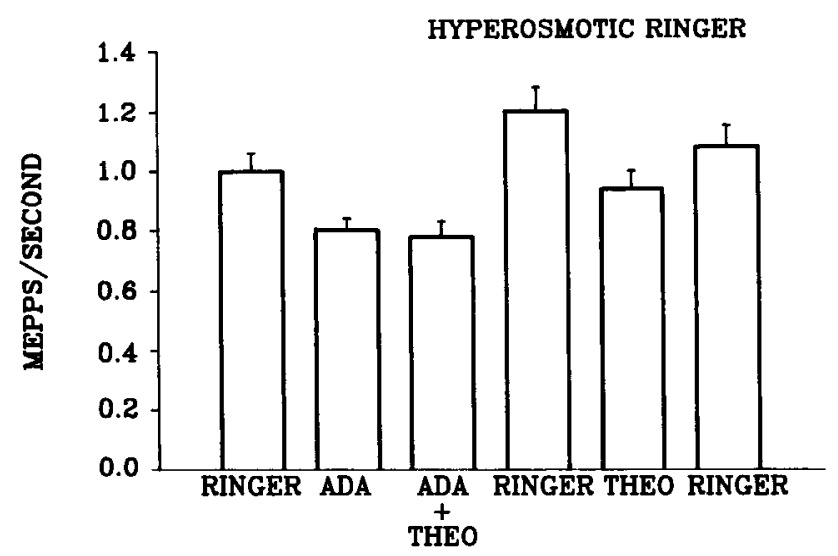

Figure 6. Presence of adenosine deaminase in the hyperosmotic Ringer's masked the depressant effect of theophylline on mepp frequency. Data represent means \pm SEM of mepp frequencies recorded during one experiment. Adenosine deaminase $(0.5$ units $/ \mathrm{ml})$ reduced mepp frequency by $20 \%(p<0.01)$. No further decrease in mepp frequency was produced by the subsequent addition of theophylline $(10 \mu \mathrm{M})$ to the hyperosmotic Ringer's containing adenosine deaminase. In the absence of adenosinc deaminasc, $10 \mu \mathrm{M}$ thcophylline inhibited mepp frequency by $22 \%(p<0.01)$. $A D A$, adenosine deaminase; $T H E O$, theophylline.

\section{Inhibitory effects of theophylline}

In normal Ringer's, theophylline produced no consistent effect on spontaneous transmitter release at a concentration of $10 \mu \mathrm{M}$. Similarly, Ribeiro and Sebastião (1985) have reported that theophylline, at concentrations at or below $50 \mu \mathrm{M}$, does not affect the nerve-evoked twitch tension of frog sartorius muscle recorded in Ringer's solution of normal osmolarity. In contrast, theophylline produced dual effects on spontaneous ACh output when the NMJ was bathed in hyperosmotic Ringer's. At $10 \mu \mathrm{M}$, theophylline depressed mepp frequency, while at concentrations greater than or equal to $100 \mu \mathbf{M}$, theophylline enhanced mepp rate. Since theophylline inhibited spontaneous transmitter release only at low micromolar concentrations, this effect may result from adenosine receptor blockade.

Other alkylxanthine drugs, such as 8-phenyltheophylline and 8-p-sulfophenyltheophylline, also depressed mepp frequency when the frog NMJ was exposed to hyperosmotic Ringer's. 8-Phenyltheophylline is a more potent adenosine receptor antagonist than theophylline but has little activity as a phosphodiesterase inhibitor (Smellie et al., 1979). 8-pSulfophenyltheophylline crosses cell membranes only to a limited extent, so that its effects may be confined to adenosine receptor blockade (Daly, 1982).

The effects of theophylline were also mimicked by adenosine deaminase, an enzyme that converts adenosine to inosine, a metabolite with no effect on neuromuscular transmission (Ginsborg et al., 1973; Ribeiro and Sebastião, 1987). In addition, the inhibitory effects of theophylline $(10 \mu \mathrm{M})$ were not seen when adenosine deaminase $(0.5$ units $/ \mathrm{ml})$ was already present in the hyperosmotic Ringer's. Thus, theophylline and adenosine deaminase may both reduce spontaneous transmitter release from frog motoneurons because they both inhibit the effects of endogenous adenosine. These results indicate that endogenous adenosine may have a second, stimulatory effect on spontaneous transmitter release.

The inhibitory and stimulatory actions of adenosine on spontaneous $\mathrm{ACh}$ release may be mediated by different types of 
A

Figure 7. Stimulatory effect of Ro201724 on mepp frequency. $A$, Mepp frequencies for 1 min recording periods were plotted against time. Ro20-1724, at $300 \mu \mathrm{M}$, reversibly enhanced mepp rate by $465 \%(p<0.001)$. $B$, This effect was accompanied by a decrease in mepp size $(p<0.001)$. Mepp amplitudes for 100 mepps in the absence and 100 mepps in the presence of $300 \mu \mathrm{M}$ Ro201724 were grouped into $0.05 \mathrm{mV}$ size bins and plotted against the frequency of their occurrence. Recordings were made in normal Ringer's.
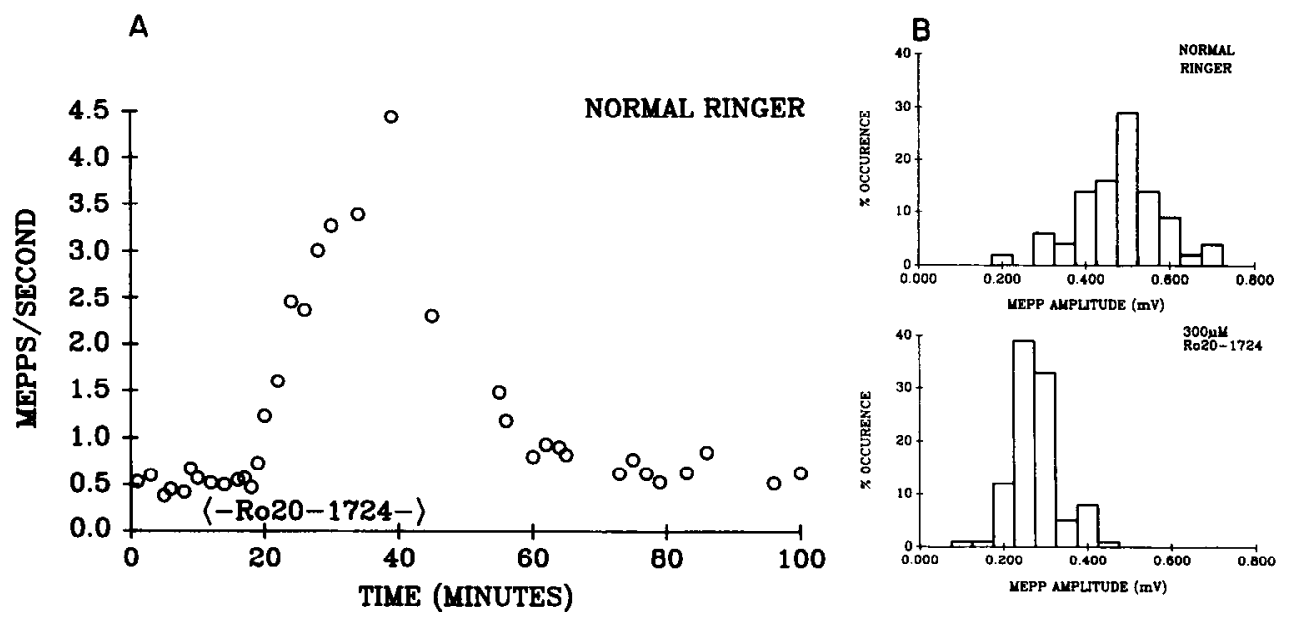

adenosine receptors on motor nerve terminals. Several classes of adenosine receptors have been found on the external membranes of many cell types, including neurons (Londos and Wolff, 1977; Van Calker et al., 1978, 1979; Daly et al., 1981). At $A_{1}$ receptors, adenosine inhibits while at $A_{2}$ receptors, adenosine stimulates the activity of the enzyme adenylate cyclase. In addition, a third class of adenosine receptors, $A_{3}$, which may be coupled to calcium channels, may be found on nerve endings (Ribeiro and Sebastião, 1986). These receptors can be distinguished pharmacologically and are all blocked by theophylline and other alkylxanthine drugs.

When adenosine is applied to the frog NMJ, its most common effect is to depress mepp frequency (Ribeiro and Walker, 1975; Brãnisteanu et al., 1979; Silinsky, 1984). Ribeiro and Sebastião (1986) have suggested that the inhibitory effect of adenosine on spontaneous release results from an intracellular action of adenosine. However, the depressant effect of adenosine on mepp frequency is blocked by theophylline (Fig. 3). Furthermore, several impermeable adenosine analogs such as $\mathrm{L}$ - and $\mathrm{D}$-phenylisopropyladenosine (PIA) and $5 '-N$-ethylcarboxamidoadenosine (NECA) also depress mepp frequency (see Barry, 1987). L-PIA is 15 times more potent than NECA and 200 times more effective than D-PIA in reducing spontaneous ACh release (Barry, 1987). The rank-order potency of these analogs in depressing spontaneous release differs from their effectiveness in inhibiting evoked release (Ribeiro and Sebastião, 1985, 1986) and suggests that adenosine inhibits spontaneous, but not evoked, release by acting at an $\mathrm{A}_{1}$-like receptor.

High concentrations of adenosine have also been reported to enhance spontaneous transmitter release (Silinsky, 1980). Furthermore, NECA, a mixed $A_{1}-A_{2}$ adenosine agonist, produces dual effects on mepp frequency (Barry, 1986b). Thus, adenosine may stimulate as well as inhibit spontaneous transmitter release. This effect may be mediated by a second adenosine receptor, perhaps of the $A_{2}$ subtype.

In normal Ringer's, the primary effect of endogenous adenosine may be to depress spontaneous ACh release. Thus, theophylline has only one action in normal Ringer's, to enhance spontaneous release. In hyperosmotic Ringer's, endogenous adenosine may both stimulate and depress spontaneous transmitter output. Thus, theophylline, in hyperosmotic Ringer's, may decrease spontaneous release at low concentrations and increase spontaneous output at high concentrations. The stimulatory effects of adenosine may be blocked at lower concentrations of theophylline than the inhibitory effects.
The effects of endogenous adenosine may differ in normal and hyperosmotic Ringer's because the source of adenosine produced endogenously at the frog NMJ may vary with the osmolarity of the Ringer's. Adenosine uptake systems, which are present on nerve terminals and on glial cells, and extracellular hydrolyzing enzymes, such as adenosine deaminase, may confine adenosine's actions to receptors located near the source of adenosine (Dowdall, 1978; Daly, 1982; Ribeiro and Sebastião, 1987). Adenosine receptors which mediate a decrease in spontaneous transmitter release may be accessible to exogenously applied adenosine or to adenosine produced endogenously in normal Ringer's. In contrast, the receptors that mediate an increase in spontaneous output may be accessible to adenosine that is produced endogenously in hyperosmotic Ringer's.

Endogenous adenosine at the NMJ may originate from several sources. Adenosine triphosphate (ATP) is released with ACh from motor nerve terminals (Silinsky and Hubbard, 1973; Silinsky, 1975) and may be hydrolyzed to adenosine by ectoenzymes in the synaptic cleft (Dowdall, 1978; Fredholm and Hedqvist, 1980; Ribeiro and Sebastião, 1987). Extracellular adenosine may be produced by this mechanism in both normal and hyperosmotic Ringer's. In addition, cells that are metabolically very active secrete adenosine which is probably produced from the intracellular hydrolysis of ATP and cyclic AMP (Fredholm and Hedqvist, 1980; Stone, 1981). When the frog NMJ is placed in hyperosmotic Ringer's solution, extracellular adenosine may be generated by such a process. For example, the increase in mepp frequency observed in hyperosmotic Ringer's may result from an increase in intracellular calcium concentration within the motor nerve terminal (Shimoni et al., 1977). This elevation in calcium levels may activate intraterminal ATP-dependent calcium sequestration systems (Blaustein et al., 1978), causing increased hydrolysis of ATP and enhanced secretion of adenosine. The adenosine, thus produced, may be accessible to stimulatory but not inhibitory receptors on the nerve terminal and may tonically enhance spontaneous transmitter release. It is this second, stimulatory effect of adenosine that may be inhibited by application of $10 \mu \mathrm{M}$ theophylline, other alkylxanthines, and adenosine deaminase.

\section{References}

Barry, S. R. (1986a) Dual effects of alkylxanthines on transmitter release at the frog neuromuscular junction. Soc. Neurosci. Abstr. 12: 992.

Barry, S. R. (1986b) Two types of adenosine receptors on frog motor 
nerve terminals mediate opposite effects on transmitter release. Biol. Bull. 171: 491 .

Barry, S. R. (1987) Adenosine depresses spontaneous transmitter release from frog motor nerve terminals by acting at an $A_{1}$ receptor. Biol. Bull. 173.

Bianchi, C. P. (1968) Pharmacological actions on excitation-contraction coupling in striated muscle. Fed. Proc, 27: 126-131.

Blaustein, M. P., R. W. Ratzlaff, and N. K. Kendrick (1978) The regulation of intracellular calcium in presynaptic nerve terminals. Annal. NY Acad. Sci. 307: 195-211.

Brãnisteanu, I. D., B. Haulicã, B. Proca, and B. G. Nhue (1979) Adenosine effects upon transmitter release parameters in the $\mathrm{Mg}^{2+}$-paralyzed neuro-muscular junction of frog. Naunyn Schmiedebergs Arch. Pharmacol. 308: 273-279.

Butcher, R. W., and E. W. Sutherland (1962) Adenosine 3',5'-phosphate in biological materials. J. Biol. Chem. 237: 1244-1250.

Croce, M. A., G. L. Kramer, and D. L. Garbers (1979) Inhibition of alkaline phosphates by substituted xanthines. Biochem. Pharmacol. 28: $1227-1231$.

Daly, J. W. (1982) Adenosine receptors: Targets for future drugs. J. Med. Chem. 25: 197-207.

Daly, J. W., R. F. Bruns, and S. H. Snyder (1981) Adenosine receptors in the central nervous system: Relationship to the central actions of methylxanthines. Life Sci. 28: 2083-2097.

Dowdall, M. J. (1978) Adenine nucleotides in cholinergic transmission: Presynaptic aspects. J. Physiol. (Paris) 74: 497-501.

Dretchen, K. L., F. G. Standaert, L. R. Skirboll, and V. H. Morgenroth III (1976) Evidence for a prejunctional role of cyclic nucleotides in neuromuscular transmission. Nature 264: 79-81.

Fain, J. N., R. H. Pointer, and W. F. Ward (1972) Effects of adenosine nucleosides on adenylate cyclase, phosphodiesterase, cyclic adenosine monophosphate accumulation, and lipolysis in fat cells. J. Biol. Chem. 247: 6866-6872.

Fatt, P., and B. Katz (1952) Spontaneous subthreshold activity at motor nerve endings. J. Physiol. (Lond.) 117: 109-128.

Fredholm, B. B., and P. Hedqvist (1980) Modulation of neurotransmission by purine nucleotides and nucleosides. Biochem. Pharmacol. 29: 1635-1643.

Fredholm, B. B., P. Hedqvist, and L. Vernet (1978) Effect of theophylline and other drugs on rabbit renal cyclic nucleotide phosphodiesterase, 5 '-nucleotidase and adenosine deaminase. Biochem. Pharmacol. 27: 2845-2850.

Furshpan, E. J. (1956) The effects of osmotic pressure changes on the spontaneous activity at motor nerve endings. J. Physiol. (Lond.) 134: 689-697.

Ginsborg, B. L., and G. D. S. Hirst (1972) The effect of adenosine on the release of the transmitter from the phrenic nerve of the rat. J. Physiol. (Lond.) 224: 629-645.

Ginsborg, B. L., G. D. S. Hirst, J. V. Maizels, and J. Walker (1973) Specificity of adenosine on transmitter output at the neuromuscular junction. Br. J. Pharmacol. 47: 637P.

Goldberg, A. L., and J. J. Singer (1969) Evidence for a role of cyclic AMP in neuromuscular transmission. Proc. Natl. Acad. Sci. USA 64: 134-141.

Katz, B. (1969) The Release of Neurotransmitter Substances, pp. 1112, Charles $\mathrm{C}$ Thomas, Springfield, IL.

Londos, C., and J. Wolff (1977) Two distinct adenosine-sensitive sites on adenylate cyclase. Proc. Natl. Acad. Sci. USA 74: 5482-5486.
Miyamolo, M. D., and B. McL. Breckenridge (1974) A cyclic adenosine monophosphate link in the catecholamine enhancement of transmitter release at the neuromuscular junction. J. Gen. Physiol. 63: 609-624.

Ribeiro, J. A., and A. M. Sebastião (1985) On the type of receptors involved in the inhibitory action of adenosine at the neuromuscular junction. Br. J. Pharmacol. 84: 911-918.

Ribeiro, J. A., and A. M. Sebastião (1986) Adenosine receptors and calcium: Basis for proposing a third $\left(\mathrm{A}_{3}\right)$ adenosine receptor. Prog. Neurobiol. 26: 179-209.

Ribeiro, J. A., and A. M. Sebastião (1987) On the role, inactivation and origin of endogenous adenosine at the frog neuromuscular junction. J. Physiol. (Lond.) 384: 571-585.

Ribeiro, J. A., and J. Walker (1975) The effects of adenosine triphosphate and adenosine diphosphate on transmission at the rat and frog neuromuscular junctions. Br. J. Pharmacol. 54: 213-218.

Sattin, A., and T. W. Rall (1970) The effect of adenosine and adenine nucleotides on the cyclic adenosine 3', 5'-phosphate content of guinea pig cerebral cortex slices. Mol. Pharmacol. 6: 13-23.

Sebastião, A. M., and J. A. Ribeiro (1985) Enhancement of transmission at the frog neuromuscular junction by adenosine deaminase: Evidence for an inhibitory role of endogenous adenosine on neuromuscular transmission. Neurosci. Lett. 62: 267-270.

Shimoni, Y., E. Alnaes, and R. Rahamimoff (1977) Is hyperosmotic neurosecretion from motor nerve endings a calcium-dependent process? Nature 267: 170-172.

Silinsky, E. M. (1975) On the association between transmitter secretion and the release of adenine nucleotides from mammalian motor nerve terminals. J. Physiol. (Lond.) 247: 145-162.

Silinsky, E. M. (1980) Evidence for specific adenosine receptors at cholinergic nerve endings. Br. J. Pharmacol. 71: 191-194.

Silinsky, E. M. (1984) On the mechanism by which adenosine receptor activation inhibits the release of acetylcholine from motor nerve endings. J. Physiol. (Lond.) 346: 243-256.

Silinsky, E. M., and J. I. Hubbard (1973) Release of ATP from rat motor nerve terminals. Nature 243: 404-405.

Silinsky, E. M., and S. M. Vogel (1987) Independent control of channel closure and block of open channels by methylxanthines at acetylcholine receptors in frog. J. Physiol. (Lond.) 390: 33-44.

Smellie, F. W., C. W. Davis, J. W. Daly, and J. N. Wells (1979) Alkylxanthines: Inhibition of adenosine-elicited accumulation of cyclic AMP in brain slices and of brain phosphodiesterase activity. Life Sci. 24: $2475-2482$.

Stone, T. W. (1981) Physiological roles for adenosine and adenosine 5 'triphosphate in the nervous system. Neuroscience 6: 523-555.

Tsuzuki, J., and R. W. Newburgh (1975) Inhibition of 5'-nucleotidase in rat brain by methylxanthines. J. Neurochem. 25: 895-896.

Van Calker, D., M. Müller, and B. Hamprecht (1978) Adenosine inhibits the accumulation of cyclic AMP in cultured brain cells. Nature 276: 839-841.

Van Calker, D., M. Müller, and B. Hamprecht (1979) Adenosine regulates via two different types of receptors, the accumulation of cyclic AMP in cultured brain cells. J. Neurochem. 33: 999-1005.

Wilson, D. F. (1974) The effects of dibutyryl cyclic adenosine $3^{\prime}, 5^{\prime}$ monophosphate, theophylline and aminophylline on neuromuscular transmission in the rat. J. Pharmacol. Exp. Ther. 188: 447-452. 